\title{
Autonomia privada e prazos prescricionais
}

\author{
Privacy autonomy and limitation periods
}

\section{Daniel Bucar Cervasio* Aline Miranda Valverde Terra**}

\section{Resumo}

\begin{abstract}
O artigo investiga, de forma crítica, a partir do método lógico-dedutivo, a proibição de convenção sobre os prazos prescricionais, disposta no art. 192 do Código Civil. Após apresentar os fundamentos da prescrição e a concepção atual de autonomia privada, o trabalho noticia recentes alterações em torno do tema na Alemanha e na França, que tendem a oferecer maior liberdade para definição convencional de prazos. Por fim, demonstra-se o tratamento do tema na legislação, doutrina e jurisprudência brasileira, que restringem excessivamente o exercício da autonomia privada no campo dos prazos prescricionais.
\end{abstract}

Palavras-chave: Autonomia privada. Prazo. Prescrição.

\section{Abstract}

The article critically investigates, from the logic-deductive method, the prohibition of the convention on the prescriptive periods, set forth in art. 192 of the Civil Code. After presenting the grounds of the prescription and the current conception of private autonomy, the recent news work changes around the subject in Germany and France, which tend to offer more freedom for conventional definition of deadlines. Finally, the treatment of the topic in Brazilian legislation, doctrine, and jurisprudence, which excessively restricts the exercise of private autonomy in the field of prescriptive periods.

Keywords: Private autonomy. Deadline. Prescription.

\section{Introdução}

Da leitura do art. 189 do Código Civil depreende-se que a prescrição extintiva é a "perda da pretensão em virtude da inércia de seu titular no prazo fixado em lei” (AMARAL, 2006, p. 565). O instituto, portanto, reúne três elementos essenciais: (a) o prazo (medida de tempo), (b) a inação do titular da pretensão e (c) o efeito extintivo da pretensão.

A compreensão de que seu fundamento envolve um interesse de ordem pública, que objetiva o afastamento da incerteza jurídica acerca do exercício da pretensão após certo período (PEREIRA, 2017, p. 572-573), fez assentar, em torno do instituto, certa rigidez normativa impeditiva do exercício da autonomia privada sobre a disciplina da prescrição, o que the atribuiria indiscutível e absoluto viés publicista. A repercussão desse preceito, no entanto, deve ser objeto de reflexão crítica, de modo a permitir a exata compreensão de quais elementos do instituto são substanciais, ou não, para o primado da segurança jurídica.

Doutor em Direito Civil pela Universidade do Estado do Rio de Janeiro e Especialista em Direito Civil pela Università degli Studi di Camerino (ITA). Procurador do Município do Rio de Janeiro, Advogado e Professor de cursos de graduação e pós-graduação. Rio de Janeiro -RJ- Brasil. E-mail: danielcervasio@yahoo.com.br.

Doutora e Mestre em Direito Civil pela Universidade do Estado do Rio de Janeiro. Professora adjunta do Departamento de Direito Civil da Universidade do Estado do Rio de Janeiro. Professora do Departamento de Direito Civil da Pontifícia Universidade Católica do Rio de Janeiro e de cursos de Pós-graduação da UERJ e da PUC/Rio. Pesquisadora Visitante do Instituto Max-Planck de Direito Privado Comparado e Internacional (Hamburgo - Alemanha). Coordenadora Editorial da Revista Brasileira de Direito Civil - RBDCivil. Associada ao Instituto Brasileiro de Direito Civil IBDCivil e à Association Henri Capitant des Amis de la Culture Juridique Française. Pesquisadora da Rede Proprietas. Rio de Janeiro -RJ- Brasil. E-mail: ammvalverde@hotmail.com. 
Alterações em torno da prescrição empreendidas nas últimas décadas pelos legisladores alemão e francês puseram em xeque o tímido papel reservado à autonomia privada sobre o instituto. Prazos convencionados e hipóteses pactuadas de interrupção e suspensão do prazo são novidades apresentadas por aqueles ordenamentos, que suscitam uma reflexão crítica do tema no ordenamento brasileiro.

Diante disso, a análise do fundamento da prescrição, juntamente com a função que atualmente se reserva à autonomia privada, permitirá uma revisão da inflexibilidade do instituto no Código Civil de 2002, cujo significativo exemplo é o seu art. 192, que veda aos contratantes dispor dos prazos prescricionais.

Contudo, somente a partir do delineamento dos aspectos que efetivamente atraem o interesse público para a prescrição (segurança jurídica), e sua conjugação com o elemento privado concorrente (interesse patrimonial), será possível identificar a real extensão da norma, e verificar se o legislador adotou a melhor solução para a promoção do interesse público.

\section{Fundamento da prescrição}

O estudo acerca do possível papel a ser desempenhado pela autonomia privada sobre os prazos prescricionais requer, inicialmente, uma reflexão sobre os fundamentos do próprio instituto da prescrição (AMAYUELAS, 2014, p. 239-240).

Sabe-se que a prescrição extintiva não era conhecida pelo antigo Direito Romano (MAINE, 1906, p. 252-253). Apenas na era pós-clássica, com o advento do Código Teodosiano (438 d.c.), tem-se notícia do primeiro delineamento do instituto. ${ }^{1}$ Tratava-se, com efeito, da previsão do prazo trintenário para o acolhimento da actio, fundado na concepção de estabilidade e certeza do direito² (TRIGGIANO, 2017, p. 40-41). A ausência do instituto da prescrição extintiva no período anterior não surpreende: sua aplicação implicaria, por certo e sob determinada perspectiva, em expropriação do direito do credor, cuja ideia não era acolhida pelos romanos (ZIMMERMANN, 2002, p. 63) e, ainda após, era rejeitada pela doutrina canônica medieval. ${ }^{3}$

Tal como hoje concebida, é possível dizer que a disciplina encontrou a primeira e melhor estruturação no ocidente por meio do direito inglês (ZIMMERMANN, 2002, p. 62). O Statute of Limitations, de 1623, fixou prazos prescricionais (de seis meses a vinte anos) em diversas matérias (direito penal, inclusive), reservando ao Rei a autorização para a tramitação de demandas além daqueles termos (TOMLINS, 1810, p. 522). A reflexão doutrinária sobre a normativa - e suas diversas e posteriores modificações - evidencia que a prescrição, para os ingleses, fundamentava-se em três aspectos: (a) o aumento da dificuldade de defesa do devedor com o transcurso do tempo; (b) o desinteresse do credo r, revelado pelo decurso do tempo, em tutelar o seu direito, a conduzir à resolução social da obrigação; e (c) o interesse público em resolver os litígios com brevidade, de modo a pacificar a sociedade sem criar incerteza, injustiça e insegurança jurídica (ZIMMERMANN, 2002, p. 63).

Iguais argumentos foram sustentados pelos codificadores continentais, de modo a fundamentar 0 acolhimento do instituto. Para os franceses, a prescrição no Code Civil representava a absorção, pelo Direito Civil, de instituto indispensável para a sociedade, pois os interesses privados eventualmente lesados

Não significa dizer que prescrição aquisitiva (usucapião) não fosse já conhecida. Afirma-se, a propósito, já estar prevista desde a Lei das XII Tábuas, conforme Menezes Cordeiro (2005, p. 15).

O item em questão foi "editado" em 438 d.c. e seu texto, juntamente com a íntegra do Código Teodosiano. Ressalta-se que em doutrina, por vezes, aponta-se certo requisito temporal de um ano para o exercício da actio romana; contudo, como já advertia a escola pandectista, tal previsão nada tem a ver com o que hoje se conhece pela prescrição extintiva: "i Romani, parlando di limitazione dell'actio quanto al tempo, non vogliono rilevare il momento specifico della facoltà di agire, il momento della facoltà d'adire il tribunale, in contrapposto alla pertinenza del diritto in sé, ma indicare la pertinenza stessa; per essi perseguibilità giudiziale è l'espressione per la pertinenza del diritto. Quando oggi si parla di prescrizione delle 'azioni' sottostiamo sempre al pericolo di dedurre, dal momento specifico della facoltà d'agire, conseguenze che sono assai poco romane" (WINDSCHEID, 1930, p. 364-365).

"La normativa sulla operatività della prescrizione risente del principio, elaborato dalla dottrina canonista medievale, secondo il quale la prescrizione sarebe uno strumento contrario alla morale" (PERLINGIERI, 2005, p. 322). 
deveriam ceder espaço à manutenção da ordem social. ${ }^{4}$ Da mesma forma, não foi outra a perspectiva de Savigny quando, na Alemanha, qualificou a prescrição como um dos mais importantes e benéficos institutos do direito civil, ${ }^{5}$ voltado para a estabilização do direito.

Ao lado do clamor por segurança jurídica, ainda são indicados outros três fatores para sustentar a prescrição. O decurso do tempo e a inação do credor ensejariam (i) a presunção de pagamento ou de renúncia ao crédito, $^{6}$ (ii) o perdão tácito da dívida (PEREIRA, 2017, p. 572) e, ainda, (iii) uma tormentosa produção de provas, ante a possibilidade de perda de documentos (recibos) e o próprio falecimento de testemunhas (PERLINGIERI, 2005, p. 322).

Não obstante esses três últimos aspectos tocarem, essencialmente, interesses privados do crédito, sobre os quais as partes poderiam deliberar mediante prévia tratativa, a doutrina não dedica maior atenção a seu respeito, e opta por acolher a ideia de que a prescrição - assim como tudo o que gira em seu entorno - encerra questão de ordem pública, pelo que, sendo cogentes as escolhas do legislador, aos interessados nada, ou quase nada, seria facultado dispor sobre a matéria.

Os Códigos Civis brasileiros de 1916 e 2002, seguindo as Ordenações, ${ }^{7}$ acolheram o instituto da prescrição, cujos fundamentos doutrinários não divergiram do pressuposto da ordem pública. Assim, a maior parte da doutrina brasileira ${ }^{8}$ fundamenta a prescrição também na necessidade de estabilização do direito (segurança jurídica), e se atribui ao instituto caráter imperativo em razão do interesse público que o reveste (BEVILAQUA, 1959, p. 351; LEAL, 1982, p. 51; DANTAS, 2001, p. 343; PEREIRA, 2017, p. 572573; TEPEDINO et al., 2007, p. 359; AMARAL, 2006, p. 566).

Contudo, uma detida observação dos instrumentos de que o instituto da prescrição dispõe, inclusive daqueles que figuram no Código Civil de 2002, faz suscitar dúvidas acerca do fundamento puramente de ordem pública que, de regra, se atribui a toda regulamentação da matéria. Se, por um lado, é possível afirmar que, de fato, a existência da prescrição advém do interesse público em garantir razoável e mínima certeza ao direito, por outro, essa conotação de ordem pública não afasta, a priori, a possibilidade das partes disciplinarem alguns aspectos do instituto consoante seus interesses patrimoniais privados, desde que, com isso, não neguem a prescrição. ${ }^{9}$ Revela-se, assim, certa feição privatista da prescrição, que ganha cada vez mais espaço em outros ordenamentos jurídicos, a exemplo do alemão e do francês, como se demonstrará adiante, e se faz presente também no direito brasileiro.

Nesse sentido, basta pensar no art. 191 do Código Civil que prevê a possibilidade de o devedor renunciar à prescrição após sua consumação: o que está em jogo não é o afastamento do instituto da prescrição; ao contrário, ele é observado e consumado, mas é dado à parte beneficiada renunciar à sua proteção, o que faz no âmbito de sua liberdade de agir, dispondo de interesses patrimoniais privados.

Aliás, a possibilidade de se negociar certos aspectos de institutos de ordem pública não é novidade no direito brasileiro. Um exemplo reforça o argumento. Com efeito, a ampla defesa consubstancia direito fundamental e de ordem pública. A concretização da garantia requer um sistema probatório, também

\footnotetext{
É o que se depreende da defesa apresentada por Bigot-Préamenau sobre a prescrição na exposição de motivos do Code Civil, in Recueil complet des travaux préparatoires du code civil. t. XV, p. 575.

5 “Die Klagverjährung gehört unter die wichtigsten und wohlthätigsten Rechtsinstitute". (SAVIGNY, 1841, p. 272).

$6 \quad$ Neste sentido, Viney (2011, p. 987). Por outro lado, argumenta-se que o transcurso do tempo teria o condão de criar uma expectativa ao devedor em torno da ausência de cobrança. Assim, a dedução de pleito após tanto tempo configuraria, inclusive, abuso do direito (estoppel). (LOUBSER, 1988, p. 36).

7 Nas Ordenações Filipinas, a prescrição assumia caráter sancionatório ao credor que se reputava e presumia negligente, em razão de não ter acionado o devedor em trinta anos (prazo que se repetia desde o Código Teodosiano). A norma se encontra no Livro 4, Título LXXIX, Das prescrições. O efeito de pena ainda é defendido por Maria Helena Diniz (2009, p. 406), apesar de não se vislumbrar, para aplicação da suposta sanção, uma violação da ordem jurídica praticada pelo credor, conforme já advertia Pereira (2017, p. 572).

8 Em doutrina, a propósito, é possível encontrar defesa do caráter meramente privado da prescrição. Ao argumentar que normas de ordem pública dispõem de forma cogente apenas sobre matéria ligada ao bem comum, esta corrente assevera que a prescrição não se enquadra em tal espírito, pois apenas busca proteger interesses patrimoniais e, na maior parte das vezes, de ordem privada. Neste sentido, Nicolau Jr. et al. (2006, p. 486-487).

9 Não por outra razão, há quem aponte ser a prescrição um instituto perene e inerente ao direito (VINEY, 2011, p. 986).
} 
revestido de interesse público. Todavia, em que pese o caráter cogente do instituto das provas, às partes é facultado sobre elas negociar, conforme previsão expressa do art. 190 do Código de Processo Civil. ${ }^{10}$

Posto, portanto, cuide-se de instituto cuja previsão e existência tocam a ordem pública, uma vez que intimamente vinculado à segurança jurídica, a possibilidade de as partes entabularem tratativas e pactos acerca de certos aspectos da prescrição, no exercício legítimo de sua autonomia privada, não tem o condão de configurar, por si só, violação à incolumidade do instituto. Significa dizer que o fato de se qualificar a prescrição como instituto de ordem pública não importa em blindar toda a sua disciplina da atuação da autonomia privada.

A segurança jurídica exige a pacificação das relações sociais, e apenas a extinção de pretensões não exercidas por determinado tempo é capaz de promovê-la. Dessa forma, o que é matéria de ordem pública - por fundamentar-se na segurança jurídica - é o instituto da prescrição em si, e não toda sua disciplina jurídica. Nessa direção, estaria vedado às partes alterar as regras legais de modo a facilitar ou dificultar enormemente a configuração da prescrição, o que importaria na negação do próprio instituto. No entanto, ser-lhes-ia facultado, a fim de melhor promover seus interesses patrimoniais privados, dispor de determinadas regras desde que, repita-se, não se conduzisse ao afastamento do instituto, e que se observassem os parâmetros de legitimidade do exercício da autonomia privada, sobre os quais se discorrerá a seguir.

\section{A contemporânea concepção de autonomia privada}

A autonomia privada, ${ }^{11}$ concebida outrora como a possibilidade de as partes se obrigarem como, quando e com quem quisessem, adquire novos contornos diante da contemporânea principiologia constitucional.

No modelo liberal clássico, o direito, confiando no jogo livre das vontades individuais, abdicava de intervir nos clausulados negociais, sob pena de ser acusado de restringir indevidamente a autonomia privada. A ordem jurídica se limitava, por conseguinte, a conferir a legalidade formal do ato de autonomia e sua correspondência à vontade das partes, mantendo-se indiferente à justeza material dos arranjos de interesses.

A passagem para o Estado Social de Direito, voltado à solidariedade, à igualdade, ao respeito à pessoa e à promoção de sua dignidade, altera, de modo significativo, a atuação estatal. Reconhece-se que, em sociedades desiguais, é a intervenção do poder público que garante e promove a liberdade da pessoa humana.

A autonomia privada deixa, então, de ser considerada valor em si mesmo, e passa a ser concebida como instrumento de promoção de finalidades constitucionalmente relevantes - como o são, a rigor, na esteira do que propugna a metodologia do direito civil-constitucional, todos os institutos jurídicos. ${ }^{12} \mathrm{Afinal}$, "querer não é poder, em um ordenamento jurídico no qual o poder é disciplinado e regulado; o querer não é poder e o poder é atribuído pelo direito e não pela vontade das partes" (PERLINGIERI, 2002, p. 173).

Se sujeita, com efeito, o ato de autonomia à dupla ordem de controle: o controle de licitude e o de merecimento de tutela. O primeiro avalia se o ato concreto contraria os bons costumes e as normas cogentes. O conceito constitucionalizado de bons costumes, segundo defende Thamis Dalsenter Viveiros de Castro (2017, p. 169), não corresponde à moral social revelada pelo passado, mas à moralidade constitucional

\footnotetext{
10 "Art. 190, CPC/15: Versando o processo sobre direitos que admitam autocomposição, é lícito às partes plenamente capazes estipular mudanças no procedimento para ajustá-lo às especificidades da causa e convencionar sobre os seus ônus, poderes, faculdades e deveres processuais, antes ou durante o processo. Parágrafo único. De ofício ou a requerimento, o juiz controlará a validade das convenções previstas neste artigo, recusando-lhes aplicação somente nos casos de nulidade ou de inserção abusiva em contrato de adesão ou em que alguma parte se encontre em manifesta situação de vulnerabilidade".

11 Luigi Ferri (2001, p. 36) define a autonomia privada como o poder, atribuído pela lei aos particulares, de criar direito, de estabelecer normas jurídicas.

12 Para análise da metodologia civil-constitucional, confira-se: Perlingieri (2005, p. 188-216); Tepedino (2008, p. 1-23); Tepedino, (2015, p. 6-9); Konder (2015, p. 193-213); Schreiber (2016, p. 1-23); Terra (2016, p. 47-70).
} 
com a qual se pretende impregnar as práticas ainda não consolidadas. ${ }^{13}$ Normas cogentes, a seu turno, são aquelas inafastáveis pela vontade das partes; cuida-se de normas que amparam interesses sociais, vale dizer, interesses de ordem pública, ${ }^{14}$ (REALE, 1999, p. 31) razão pela qual é vedado aos contratantes dispor de modo diverso. ${ }^{15} \mathrm{Em}$ suma, são normas de direito privado que tutelam interesses coletivos, daí a maior proteção conferida pelo Estado (PEREIRA, 2017, p. 14). Incluem-se nessa categoria de normas, por exemplo, o art. 1.521, I, do Código Civil, segundo o qual é proibido o casamento entre ascendente e descendente, qualquer que seja o grau de parentesco, e o art. 1.566, que impõe a ambos os cônjuges a dever de mútua assistência. Como se verá a seguir, o art. 192, objeto desta análise, também encerra norma cogente, inafastável, por conseguinte, pela vontade das partes.

O juízo de merecimento de tutela, por sua vez, analisa a idoneidade do ato concreto para a efetiva promoção de valores fundamentais do ordenamento jurídico (PERLINGIERI, 2005, p. 425). O merecimento de tutela se reconduz à análise de justificação do ato a partir dos seus efeitos, não à avaliação estrutural, seara do juízo de licitude. Cuida-se, pois, da verificação da coerência dos efeitos perseguidos pelo ato de autonomia com os valores supremos da ordem jurídica: enquanto a inobservância das normas imperativas conduz a um déficit estrutural, o não atendimento aos valores fundamentais acarreta um déficit funcional. Trata-se, em definitivo, da necessidade de conformação, em cada caso, dos atos de autonomia ao projeto constitucional.

Releva, nesse processo de redefinição da autonomia privada, a boa-fé objetiva, desenvolvida na Alemanha, sobretudo após a edição, em 1900, do $B G B, 16,{ }^{17}$ com o propósito de corrigir os excessos da liberdade individual. ${ }^{18}$ Firmando-se como princípio de lealdade recíproca entre os contratantes, a boafé objetiva erige-se como obstáculo ao exercício da autonomia privada em violação "aos parâmetros de convivência e confiança mútuas que devem reger um ambiente negocial sadio" (SCHREIBER, 2013, p. 53), ajustando, quando necessário, a disciplina contratual estabelecida pelas partes, de acordo com as especificidades da concreta relação negocial (PERLINGIERI, 2005, p. 460). A boa-fé objetiva "concorre na criação da regula iuris do caso concreto" (PERLINGIERI, 2005, p. 461), mesmo no âmbito de relações paritárias, construindo a disciplina negocial não apenas preenchendo eventuais lacunas deixadas pelas partes, mas, sobretudo, modificando "substancialmente o dictum originário, no quadro de uma retificação que visa garantir a concreta realização dos objetivos conjuntamente prefigurados pelos contratantes" (SPADAFORA, 2007, p. 212).

Ao lado da boa-fé objetiva, outro inafastável parâmetro de legitimidade do exercício da autonomia privada é a renovada concepção do princípio do equilíbrio econômico, que deixa de ser analisado sob aspecto meramente procedimental, pelo qual bastava que a avença fosse fruto de consenso livre, suficientemente ponderado e adequadamente informado, para ser considerada justa, ${ }^{19} \mathrm{e}$ passa a exigir o balanceamento entre a livre iniciativa - fundamento constitucional da autonomia contratual - e a solidariedade

13 Tome-se, por exemplo, o disposto no art. 122 do Código Civil, segundo o qual são lícitas, em geral, as condições que não contrariem os bons costumes. Adotando-se o conceito constitucionalizado de bons costumes, é possível reputar ilícita qualquer condição que pretenda restringir a autonomia existencial em prol de interesses patrimoniais, uma vez que a Constituição da República de 1988 impõe justamente o contrário: a instrumentalização das situações jurídicas patrimoniais à promoção daquelas existenciais. Nessa direção, é ilícita, em contrato de prestação de serviços médicos de reprodução humana assistida, a cláusula que condiciona a gratuidade do serviço à doação de óvulos para a clínica que realiza os procedimentos, a invalidar o próprio contrato. O exemplo é amplamente desenvolvido por Viveiros de Castro (2017, p. 249 et. seq.).

14 De acordo com Clovis Bevilaqua (1955, p. 13, grifos no original), normas de ordem pública são aquelas "que, em um Estado, estabelecem os princípios, cuja manutenção se considera indispensável à organização da vida social, segundo os preceitos do direito civil".

15 Como ensina San Tiago Dantas (2001, p. 44), "as normas imperativas constituem o que chamamos jus cogens, São aquelas que vinculam as partes atingidas pelas suas disposições. Todos devem obediência a esta norma enquanto a considerarmos como norma de conduta; e o juiz, chamado a aplica-la na composição de um conflito, não pode deixar de se socorrer delas".

16 Cuidam especialmente do tema os $\S \S 157$ e 242 do BGB: $\S 157$. "Os contratos interpretam-se como o exija a boa-fé, com consideração pelos bons costumes do tráfego"; e $\S 242$. "O devedor está adstrito a realizar a prestação tal como o exija a boa-fé, com consideração pelos costumes do tráfego" (CORDEIRO, 2001, p. 325)

17 Sobre o sentido inicial da boa-fé no BGB e sua posterior evolução, confira-se: Cordeiro (2001, p. 331 et seq.).

18 Embora, quando da edição do $B G B$, a utilização da boa-fé tenha ficado restrita aos exatos limites referidos nos $\S \S 157$ e 242 , a eclosão da Primeira Guerra Mundial levou os Tribunais alemães a aplicá-la de forma mais ampla, de modo a criar, sob o "guarda-chuva" do § 242, diversas regras que dele não constavam expressamente. O processo se intensificou com a Segunda Guerra Mundial: "again § 242 BGB was invoked, and today it is a 'king' of the BGB". De todo modo, "later the legislator codified some of the institutions which the courts had established, for instance hardship [...]" (LANDO, 2007, p. 603-604).

19 Ainda nesse sentido, afirmando que a autonomia privada se sujeita apenas a controle de licitude e aquele de ordem procedimental, confira, na doutrina italiana, Moscati (2010, p. 1204). 
social. Nessa direção, impõe-se que as vantagens ou benefícios econômicos conferidos às partes sejam proporcionais entre si. A justiça contratual, expressão da justiça comutativa, não requer equivalência absoluta nas relações de troca, mas proporcionalidade, de forma que nenhuma das partes dê muito mais nem muito menos do que recebeu. ${ }^{20}$

Por fim, completa o juízo de merecimento de tutela do ato de autonomia a aferição do atendimento da função social do contrato. Inserida no art. 421 do Código Civil, a função social passou a exigir dos contratantes o dever de perseguir, além da satisfação de seus interesses particulares, a promoção de interesses extracontratuais socialmente relevantes dignos de tutela e relacionados ao contrato (TEPEDINO, 2009, p. 150). Ao lado da promoção de sua função econômica, conferindo aos contratantes a utilidade que o ordenamento jurídico lhe atribui, o contrato deve promover interesses sociais merecedores de tutela que, de alguma forma, sejam afetados pela relação contratual, não os deixando sucumbir aos contrários interesses das partes. ${ }^{21}$

Nesse cenário, é de se notar que a autonomia privada ingressa no século XXI profundamente remodelada. Não se trata de nova roupagem para velho conceito, mas de novo conceito forjado pela legalidade constitucional. E é precisamente nessa ambiência que se impõe avaliar a possibilidade de as partes, no exercício de sua autonomia, alterar os prazos prescricionais.

\section{As recentes alterações legislativas na Alemanha e na França}

Como observa Zimmermann (2008), a análise da evolução da disciplina da prescrição ao longo dos últimos cem anos indica algumas tendências normativas, dentre as quais se destacam: i) fixação de prazos uniformes para a prescrição; ii) estabelecimento de prazos não muito curtos (inferior a seis meses) nem muito extensos (superior a trinta anos); iii) fixação do dies a quo de acordo com o conhecimento (efetivo ou reputado), pelo credor, da identidade do devedor e dos fatos que ensejaram o nascimento da pretensão; e iv) reconhecimento de que a prescrição tem um efeito "débil": não extingue o direito do credor, mas apenas permite ao devedor se negar a cumprir a pretensão. ${ }^{22}$ No que tange especificamente à possibilidade de as partes alterarem os prazos prescricionais, os pactos que facilitam a prescrição têm sido amplamente reconhecidos pelos ordenamentos jurídicos, ao contrário daqueles que a dificultam. No entanto, duas recentes reformas, no $B G B$ e no Code Civil, parecem contrariar a tendência observada, uma vez que permitiram, além da redução, a ampliação, pelas partes, dos referidos prazos.

Na Alemanha, a reforma do regime da prescrição entrou em vigor em $1^{\circ}$ de janeiro de 2002 , com a Lei de Modernização do Direito das Obrigações. A nova redação do §202 BGB prevê, sob a enganosa rubrica ${ }^{23}$ "inadmissibilidade dos pactos sobre a prescrição", a possibilidade de as partes disporem sobre os prazos prescricionais com maior liberdade do que no regime anterior. ${ }^{24} \mathrm{De}$ acordo com o dispositivo,

(1) O prazo prescricional não pode ser previamente reduzido por negócio jurídico em casos de responsabilidade por dolo.

(2) O prazo prescricional não pode, por negócio jurídico, ser majorado para um prazo maior que trinta anos, a partir do início legal de seu cômputo. ${ }^{25}$

20 De acordo com Pietro Perlingieri (2000, p. 560, tradução livre), o princípio de proporcionalidade parece "destinado a afetar profundamente a moderna concepção de contrato, que de tal forma se distancia definitivamente da tradicional interpretação voluntarista do princípio pacta sunt servanda".

21 A interpretação da locução "em razão de", constante do texto do dispositivo legal, ajusta-se à concepção segundo a qual a função social do contrato não é unicamente um limite externo à liberdade de contratar, mas interno, imprescindível para a configuração e identificação do instituto e, por certo, de necessário atendimento para atribuição de tutela pelo ordenamento. Como explica Maria Celina Bodin de Moraes (2005, p. 118-119, grifos no original), quando a lei determina que "a liberdade de contratar será exercida em razão e nos limites da função social do contrato", é possível concluir que a liberdade de contratar não se dará mais "em razão da vontade privada, como ocorria anteriormente, mas em razão da função social que o negócio está destinado a cumprir". Confira-se, ainda, ao propósito, Martins-Costa (2004).

22 Para análise do processo de reforma do regime jurídico da prescrição, confira-se Zimmermann (2008, p. 145-146).

A crítica é de Zimmermann (2008, p. 177).

24 Segundo a dicção do $\S 225$ BGB anterior à reforma, o regime da prescrição era unilateralmente imperativo: as partes poderiam facilitar a prescrição, reduzindo os prazos, mas não poderiam dificultá-la, ampliando os prazos legais.

25 Tradução livre de: “(1) Die Verjährung kann bei Haftung wegen Vorsatzes nicht im Voraus durch Rechtsgeschäft erleichtert werden. (2) Die Verjährung kann durch Rechtsgeschäft nicht über eine Verjährungsfrist von 30 Jahren ab dem gesetzlichen Verjährungsbeginn hinaus erschwert werden." 
Como se nota, há apenas duas limitações à alteração dos prazos: i) não é possível pactuar antecipadamente sua redução em caso de responsabilidade por dolo; e ii) não se admite o ajuste de prazo superior a trinta anos, contados do início legal do seu decurso. ${ }^{26} \mathrm{O}$ limite máximo de trinta anos se justifica, segundo a doutrina germânica, em homenagem à tutela do interesse público, que restaria gravemente violado caso se permitisse que as partes excluíssem a possibilidade de prescrição, criando hipóteses contratuais de pretensões imprescritíveis ${ }^{27}$ (ZIMMERMANN, 2008, p. 177).

A despeito de o dispositivo se localizar sistematicamente ao final do Título 1 ("Objeto e prazo da prescrição") da seção do BGB dedicada à prescrição, a norma não trata apenas das matérias disciplinadas nos §§ 194 a 201 BGB - a saber, prazo e início do cômputo da prescrição -, mas alcança também os pactos concernentes a outros aspectos do regime, como seus efeitos e causas de suspensão (ZIMMERMANN, 2008, p. 178).

O direito alemão atribui, portanto, amplo espaço de atuação à autonomia privada, e a tradicional feição publicística da prescrição cede passo em favor da ampliação de seu perfil privatístico. Isso se deve, em grande medida, ao fato de lá se reconhecer que a prescrição desempenha não apenas a função de tutelar o interesse público, mas, sobretudo, de tutelar o devedor, razão pela qual "where he renounces such protection, the exercise of his private autonomy may well be seen to prevail over the public interest" (ZIMMERMANN, 2002, p. 164).

$\mathrm{Na}$ França, o incremento do exercício da autonomia privada em relação aos prazos prescricionais se deu no âmbito de grande reforma legislativa do Code Civil, ocorrida por meio da Loi du 17 juin 2008. Curiosamente, as alterações foram fruto das comemorações do bicentenrário do Code, ocorridas em 2004, que resultaram em movimento de restauração (ou recodificação) do diploma, liderado, quanto à parte do Direito das Obrigações, por Pierre Català. ${ }^{28}$

No que toca à disciplina da prescrição, o sentimento em favor de reforma era geral. $\mathrm{O}$ instituto era alvejado por duras críticas em doutrina, ${ }^{29}$ o que resultou em ampla modificação, sobretudo em relação aos prazos prescricionais. Especificamente quanto à convenção sobre os prazos, o legislador francês caminhou no mesmo sentido da reforma alemã.

De todo modo, convém destacar que antes das alterações implementadas pela Lei de 2008, a doutrina francesa posicionava-se contrariamente à possibilidade de alongamento dos prazos prescricionais, sob pena de nulidade da cláusula negocial (FLOUR et al., 2015, p. 1161). A razão da proibição repousava na vedação à renúncia prévia da prescrição, prevista no art. $2220^{30}$. Afirmava-se que o dispositivo traduzia regra de proteção ao devedor, a fim de evitar que, diante de credor (a princípio) mais forte, se visse constrangido a aceitar o abrandamento de sua proteção.

Em sentido diametralmente oposto, a redução dos prazos já era admitida de forma ampla, pois se entendia que semelhante pacto concretizaria, na realidade, a garantia de proteção do devedor, objetivada pelo Code. Embora a questão tenha sido alvo de viva controvérsia em outros países (inclusive no Brasil, como adiante se verá), a possibilidade de convenção acerca da redução de prazos era acolhida, desde

26 Sobre o início do cômputo do prazo geral de prescrição, confira-se o § 199 BGB que, embora tenha adotado o sistema subjetivo, introduziu certos paliativos:"Ressalvada fixação diversa, a prescrição começa no fim do ano em que (1.) a pretensão nasceu e (2.) o credor teve conhecimento das circunstâncias que fundamentam a pretensão e a identidade do devedor, ou teria delas ter conhecimento sem grave negligência".Tradução livre de: "Die regelmäßige Verjährungsfrist beginnt, soweit nicht ein anderer Verjährungsbeginn bestimmt ist, mit dem Schluss des Jahres, in dem (1.) der Anspruch entstanden ist und (2.) der Gläubiger von den den Anspruch begründenden Umständen und der Person des Schuldners Kenntnis erlangt oder ohne grobe Fahrlässigkeit erlangen müsste". Sobre a adoção do sistema subjetivo pelo BGB, confira-se Canaris (2004, p. 111 et seq.) (NORDMEIER, 2004, p. 218-219).

27 Como observa Menezes Cordeiro (2002) “alguns juristas mais liberais, particularmente os afectos à teoria económica do Direito, haviam reclamado uma margem ainda maior de autonomia privada".

28 Daí o nome L'Avant Projet Català. Para pesquisa acerca do movimento: Fauvarque-Causson e Mazeaud (2006, p. 103-106).

29 Em relação ao tema, a doutrina francesa apontava toda sorte de problemas: a ausência de racionalidade na escolha dos prazos, a indeterminação de certos prazos, o conflito entre os termos, dentre outros aspectos (BEHAR-TOUCHAIS, 2000, p. 12-18).

30 Em tradução livre: "Não se pode, antecipadamente, renunciar à prescrição; pode-se renunciar à prescrição consumada". 
$1895,{ }^{31}$ pela jurisprudência francesa ${ }^{32}$ (CARIO, 1998, p. 9-12). Diante desse quadro, em que já se admitia certa liberdade negocial no campo da prescrição, a Loi de 17 juin 2008 introduziu o art. 2254, com o seguinte texto:

\begin{abstract}
O prazo da prescrição pode ser reduzido ou majorado por acordo das partes. Não pode, todavia, ser reduzido a menos de um ano nem estendido a mais de 10 anos.

As partes poderão, igualmente e em comum acordo, acrescentar causas de suspensão ou interrupção além das previstas em lei.

As disposições das alíneas precedentes não são aplicáveis às pretensões de pagamento ou repetição de salários, pagamentos de rendas, pensão alimentícias, benefícios, encargos locatícios, juros de empréstimos e, em geral, às pretensões de pagamento com periodicidade anual ou inferior. ${ }^{33}$
\end{abstract}

Duas inovações se destacam na experiência francesa.

A primeira diz respeito à possibilidade de as partes alongarem o prazo prescricional até o limite de dez anos. Embora a extensão do prazo fosse entendida como pressuposto prejudicial ao devedor, certo é que nos debates da alteração legislativa verificou-se que os contratantes já tinham à sua disposição outros instrumentos que permitiam o alongamento dos termos. Nesse sentido, durante os debates em torno do Anteprojeto Català, os parlamentares argumentaram que, se por meio das ferramentas de suspensão e interrupção era lícito às partes alongarem os prazos legais, nenhuma razão haveria para que elas não pudessem pactuar previamente a majoração. ${ }^{34}$

A outra inovação se refere ao campo das relações abrangidas pela possibilidade de estabelecimento de novos prazos. Além das restrições previstas em lei especial, ${ }^{35}$ a alínea 3 do art. 2254 afasta a convenção quanto a obrigações periódicas que tocam situações tipicamente desiguais, tais como a relação trabalhista, locatícia e de mútuo. Protege-se, nesse sentido, o devedor mais fraco (FLOUR et al., 2015, p. 1163).

Embora seja possível notar uma maior ousadia no legislador francês quanto ao estabelecimento do prazo máximo a ser pactuado - já que o legislador francês estabeleceu prazo máximo decenal contra o trintenário alemão -, verifica-se que ambos os ordenamentos, de toda forma, ampliaram significativamente o exercício da autonomia privada dos contratantes em relação à prescrição, a demonstrar que, nesses países, nem toda a regulamentação da prescrição encerra questão de ordem pública.

\title{
5 Imperatividade dos prazos prescricionais no direito brasileiro
}

O Código Civil de 1916 não previu expressamente, tal qual o Código de 2002, a proibição de as partes pactuarem a alteração dos prazos prescricionais (art. 192). Não obstante, a ausência normativa ensejou certo debate acerca da possibilidade, ou não, de convenção relativa à redução dos prazos. Com efeito, a codificação antecedente apenas previa, tal como o texto original do Code Civil, a proibição da renúncia prévia à prescrição: Art. 161 - A renúncia da prescrição pode ser expressa, ou tácita, e só valerá, sendo feita, sem prejuízo de terceiro, depois que a prescrição se consumar.

\footnotetext{
31 Chambre civile de la Cour de cassation, 4 décembre 1895, conforme Proposition de loi portant réforme de la prescription en matière civile. Disponível em: <http://www.senat.fr/rap/l07-083//07-08310.html>. Acesso em: 19 fev. 2017.

32 Há que se ressalvar, todavia, hipóteses em que o devedor é mais forte que o credor, como pode ocorrer na relação consumerista, para a qual a legislação francesa afastou expressamente a possibilidade de as partes pactuarem os prazos, conforme Code de la Consommation, art. 313-16.

33 Tradução livre de: “Art. 2554. La durée de la prescription peut être abrégée ou allongée par accord des parties. Elle ne peut toutefois être réduite à moins d'un an ni étendue à plus de dix ans. Les parties peuvent également, d'un commun accord, ajouter aux causes de suspension ou d'interruption de la prescription prévues par la loi. Les dispositions des deux alinéas précédents ne sont pas applicables aux actions en paiement ou en répétition des salaires, arrérages de rente, pensions alimentaires, loyers, fermages, charges locatives, intérêts des sommes prêtées et, généralement, aux actions en paiement de tout ce qui est payable par années ou à des termes périodiques plus courts".

34 Proposition de loi portant réforme de la prescription en matière civile. Disponível em: <http://www.senat.fr/rap//07-083/I07-08310.html>. Acesso em: 19 fev. 2017.

35 Vide ressalva da nota 59.
} 
A partir desse dispositivo, a doutrina brasileira entendeu, de forma unânime, que não era dado às partes negociar a dilação do prazo, pois, na lição de Clóvis Beviláqua (1959, p. 370), a lei não desejava o alongamento indefinido do prazo por força da expressa vedação à renúncia.

A cisão doutrinária, entretanto, foi destinada ao encurtamento convencional do prazo prescricional. Entre aqueles que defendiam a redução figura o próprio Clóvis Beviláqua (1959, p. 370), que argumentava ser a prescrição fundada na paz social e na ordem pública, razão pela qual a diminuição do prazo reforçaria a função do instituto, pelo que deveria ser admitida. Nesse exato sentido, é a sua advertência: "Encurtar, porém, o prazo, é diminuir a resistência do direito, a que a prescrição se opõe; é, portanto, robustecê-la, dar-Ihe maior energia".

Às conclusões de Beviláqua, por argumentos, às vezes, diversos, aderiram Carvalho de Mendonça (1908), ${ }^{36}$ Carvalho Santos (1984, p. 377-388) Antônio Luís Câmara Leal, ${ }^{37}$ (1982) Serpa Lopes ${ }^{38}$ (1989), Caio Mário da Silva Pereira (1994, p. 445) e Orlando Gomes (2000, p. 499).

Em sentido oposto, Ary Azevedo Franco (1940) noticia que a vedação à redução dos prazos adviria de decisão deliberada do legislador, que expressamente rejeitara norma que previa a possibilidade de diminuição. ${ }^{39}$ Trilhando o mesmo entendimento, Pontes de Miranda (2013, p. 446), sem declinar uma argumentação crítica, afirmava que "o prazo de prescrição não pode ser diminuído, nem aumentado, por meio de negócio jurídico. Só a regra jurídica pode aumentá-lo, ou diminuí-lo”. Da mesma forma e sem maiores reflexões, Carlos da Rocha Guimarães (1980, p. 103) asseverou que: "Se os prazos são fixados em lei, no sentido de estabelecer a pacificação social e a certeza jurídica, é evidente que os particulares não podem alterar um dispositivo legal, modificando os prazos nele previstos." 40

O Código Civil de 2002, por sua vez, colocou fim à controvérsia, ao dispor, no art. 192, que "os prazos de prescrição não podem ser alterados por acordo das partes". ${ }^{41}$ Como se vê, de lege lata, o legislador não deixou dúvidas acerca do caráter cogente do dispositivo, pelo que, de regra, é vedado às partes ampliar ou reduzir os prazos prescricionais. A excessiva limitação à autonomia privada, contudo, parece ir de encontro ao aspecto privatista que, ao lado do interesse público, se vislumbra no instituto, ${ }^{42}$ decorrente do reconhecimento de que a tutela da segurança jurídica não é posta em xeque quando se permite que as partes disciplinem certos aspectos da prescrição relativos a interesses patrimoniais privados, desde que não afastem ou embaracem, ainda que por via oblíqua, a aplicação do instituto. Em verdade, não se identifica fundamento legítimo para tão intensa restrição; as razões apontadas pela doutrina não se afiguram suficientes a conferir legitimidade à tamanha limitação da autonomia privada.

Afirma-se, por exemplo, que a vedação à alteração convencional dos prazos prescricionais visa evitar que a parte mais forte subjugue a vontade do mais fraco, impondo-lhe um prazo excessivamente extenso ou exíguo, conforme o caso. ${ }^{43} \mathrm{~A}$ afirmação, por si só, não se sustenta como fundamento da proibição, por três razões principais.

\footnotetext{
36 "Ninguém pode por acto unilateral ou por contracto renunciar à prescripção antes de consumada, pois que é ella do interesse social. Se isto fosse permitido, não tardaria essa renuncia como clausula imposta pelo credor em todos os títulos creditórios" (MENDONÇA, 1908, p. 517).

37 "O interesse público visado pela prescrição é limitar a duração do estado de incerteza do direito, pelo não-exercício da ação destinada a fazê-lo valer, quando violado, de modo que estabelecer um limite menor do que o determinado pela lei é antes favorecer, do que contrariar, o interesse público que ela teve por fim assegurar" (LEAL, 1982, p. 54).

38 "Mas nenhum prejuízo há, tanto que o próprio Código Civil alemão, no art. 225, depois de prescrever que a prescrição não pode excluir-se nem ser dificultada, acrescenta: é admissível a facilitação da prescrição, especialmente o encurtamento da mesma". (LOPES, 1989, p. 526).

39 A norma rejeitada, conforme assevera Ary Franco (1940, p. 26), tinha a seguinte dicção: "É lícito estipularem-se nos contractos meios que facilitem a realisação da prescripção, e a diminuição dos prasos estabelecidos neste caso para ella".

40 À negativa da possibilidade de redução do prazo ainda partilha do mesmo entendimento Achiles Bevilaqua (1954, p. 66): "Não é permitido abreviar, por convenção das partes, o prazo de prescrição, que é instituto de ordem pública. A cláusula aparece, frequentemente, nos chamados contratos de adesão, como o seguro, nos quais o devedor é quem impõe a sua vontade ao credor".

41 Vale notar que, apesar de toda controvérsia acerca da questão, não é possível encontrar um registro de debate quanto ao tema nos trabalhos parlamentares desenvolvidos na tramitação do Projeto do Código Civil, consolidado em Menck (2012).

42 Câmara Leal (1982, p. 54), já na década de 70, reconhecia a feição privatista da prescrição quando aplicável às relações de direito privado.

43 Na Itália, cujo Código Civil prevê, no art. 2936, a mesma restrição à autonomia privada, a doutrina a justifica na razão apontada no texto. Confirase, a título de exemplo, Roselli (2009, p. 497).
} 
Em primeiro lugar, em qualquer relação contratual, as partes buscam alcançar posições de vantagem, e a ordem jurídica não as impede de fazê-lo, afinal, referida postura é mesmo da essência das relações negociais. Nem mesmo a incidência da boa-fé objetiva seria capaz de alterar tal perspectiva, impondo aos contratantes o sacrifício de situações de preponderância em favor da contraparte, eis que o princípio não se confunde, em definitivo, com atribuição de função abnegatória ou altruísta ao contrato. No âmbito de relações paritárias, o que o princípio exige é a atuação leal e honesta, por meio da imposição de "deveres de colaboração que são condicionados e limitados pela função social e econômica do negócio celebrado". ${ }^{44}$ (TEPEDINO et al., 2005, p. 41). Nessa esteira, fosse possível a convenção sobre os prazos prescricionais, a legitimidade do exercício da autonomia privada estaria subordinada à observância dos ditames da boafé objetiva, como se verá adiante, a impedir que o comportamento desonesto e desleal de uma parte acabasse por lhe garantir um prazo prescricional mais favorável.

Sublinhe-se ainda que, cuidando-se de contratos de adesão, em relação paritária ou não, aplica-se o art. 424 do Código Civil, segundo o qual "são nulas as cláusulas que estipulem a renúncia antecipada do aderente a direito resultante da natureza do negócio". A despeito de o conceito técnico de "direito resultante da natureza do negócio" remeter "à espécie negocial, ao tipo de contrato efetivamente celebrado pelas partes" (TEPEDINO, 2006, p. 57), há que se estender a nulidade a toda renúncia a direito que seja essencial para a consecução do resultado útil programado. Nessa direção, a renúncia ao prazo prescricional legal, com imposição ao aderente de prazo superior ou inferior em seu prejuízo, por embaraçar a consecução do resultado útil e a satisfação de seus interesses, seria fulminada de nulidade.

Por fim, se restasse configurada a vulnerabilidade de uma das partes, o art. 192, embora útil por trazer de forma expressa a proibição de alteração do prazo, não seria para tanto indispensável, uma vez que o ordenamento jurídico brasileiro já prevê instrumentos eficazes específicos de contenção do contratante em posição de superioridade, a exemplo da nulidade das cláusulas que "impossibilitem, exonerem ou atenuem a responsabilidade do fornecedor por vícios de qualquer natureza dos produtos ou serviços ou impliquem renúncia ou disposição de direitos", prevista no art. 51, inciso I, do Código de Defesa do Consumidor, cuja vocação expansiva permite sua aplicação inclusive a relações que não sejam tecnicamente de consumo. ${ }^{45}$

Com efeito, como bem demonstram as experiências alemã e francesa, a promoção de segurança jurídica e a proteção do interesse público não requerem o estabelecimento de regime jurídico mandatório para a prescrição; em algumas situações e observados certos parâmetros, a autonomia privada pode legitimamente prevalecer, como aponta Zimmermann (2002, p.166):

Public interestdoes not require a prescription regime to be mandatory: party autonomy may, to a large extend, prevail. The public interest is not adversely affected if a claim prescribes in seven rather than three years - not sufficiently adversely affected, at any rate, to override the decision of a debtor to waive his protection by agreement with his creditor. ${ }^{46}$

Nessa direção, é possível promover a segurança jurídica, proteger o interesse público, estabilizar as relações sociais e tutelar o devedor, por meio do estabelecimento, ao lado dos prazos específicos de prescrição referentes às diversas pretensões, de prazos prescricionais gerais mínimo e máximo, ${ }^{47}$

${ }^{44}$ Na mesma direção, confira-se Bianca (2004, p. 197, grifos no original): "Es necesario por lo tanto avanzar hasta qué punto la parte debe tener en cuenta los legítimos intereses de la contraparte. La especificación debe ser buscada en el límite del apreciable sacrificio, que circunscribe el deber de buena fe: precisamente, la buena fe requiere a la parte tener presente la utilidad de la contraparte en los límites en los cuales ello no importe un apreciable sacrificio".

45 Nessa direção, sustenta Gustavo Tepedino (2004, p. 244): “Acredito, entretanto, que será possível tranquilamente a aplicação do Código de Defesa do Consumidor, mesmo em situações em que não haja propriamente relação de consumo, desde que identifiquemos os pressupostos essenciais de hipossuficiência que justificam e dão legitimidade normativa là tutela do consumidor. Este, antes de ser consumidor, é pessoa humana, para cuja proteção se volta inteiramente o constituinte. Cuida-se de localizar, portanto, os pressupostos essenciais que, segundo o Código de Defesa do Consumidor, são necessários e suficientes para atrair uma série de princípios em defesa do sujeito de direito em situação de inferioridade".

46 E prossegue o autor, na mesma sede: "The debtor should, however, be able to agree upon a period of, say, fifty years since that would effectively exclude the claims against him from prescription" (ZIMMERMANN, 2002, p. 166).

${ }_{47}$ Na esteira da imensa maioria da doutrina, Caio Mário da Silva Pereira (1994, p. 582) afirma que a possibilidade de dilação do prazo importaria renúncia antecipada da prescrição, o que é vedado expressamente pelo art.191: "Sua extensão equivaleria a uma renúncia parcial, na proporção em que é alongado, e, desta sorte, de alongamento em alongamento, chegar-se-ia à renúncia à própria prescrição, o que é defeso (Código Civil art. 191)". No entanto, o estabelecimento, na lei, de prazo máximo, como se sugere de lege ferenda, impede, a toda evidência, que a ampliação do prazo se converta em renúncia antecipada. 
franqueando às partes a liberdade de, dentro de tais limites, escolher o prazo mais adequado a tutela de seus interesses privados, observados, evidentemente, os princípios do equilíbrio econômico, da boa-fé objetiva e da função social do contrato. ${ }^{48}$

A escolha de prazo prescricional diverso do legalmente previsto inserir-se-ia, assim, no contexto da gestão dos riscos contratuais: permitir-se-ia às partes definir por quanto tempo o devedor deveria suportar os riscos do seu inadimplemento e a partir de que momento esses riscos passariam a ser atribuídos ao credor. Ajustando-se prazo superior àquele previsto em lei, imputar-se-ia ao devedor risco maior do que o comumente assumido; de outro lado, se o prazo prescricional fosse inferior ao legal, o incremento do risco seria do credor. Referida alocação de riscos integraria a equação econômica desejada pelos contratantes, devendo observar o princípio do equilíbrio econômico do contrato.

A boa-fé objetiva, ao concretizar o princípio constitucional da solidariedade social na esfera contratual, transformando as relações obrigacionais em espaço de cooperação e solidariedade (NEGREIROS, 2002, p. 117), passou a impor aos contratantes que se empenhem em promover os interesses da contraparte, que adotem conduta proba e honesta, que prestem todas as informações necessárias não apenas à celebração do contrato, como também ao adimplemento da prestação. Dessa forma, admitindo-se a alteração do prazo prescricional, exigir-se-ia que a mudança também estivesse de acordo com essa nova noção de ordem pública contratual, pelo que não prevaleceria se, em flagrante violação aos ditames da boa-fé objetiva, ensejasse a sobreposição ilegítima dos interesses de uma das partes em relação aos da contraparte. Por fim, o novo prazo prescricional jamais poderia violar direitos extracontratuais merecedores de tutela que, de alguma forma, se relacionassem com o contrato, sob pena de violação da função social do contrato.

Nota-se, portanto, que a vedação à alteração do prazo prescricional por ajuste contratual impõe restrição desproporcional à autonomia privada, já que é possível garantir a segurança jurídica e tutelar o interesse público com menor sacrifício à liberdade dos contratantes por meio da imposição legal de limites mínimo e máximo dentro dos quais as partes poderiam legitimamente decidir; observados, sempre, os princípios do equilíbrio econômico, da boa-fé objetiva e da função social do contrato. ${ }^{49}$

Além disso, a proibição do art. 192 parece entrar em rota de colisão, em parte, com a possibilidade de interrupção da prescrição, cujo efeito, ao fim e ao cabo, é justamente a ampliação do prazo prescricional. Nesse caso, diversamente da alteração contratual, a ampliação do prazo se dá após o nascimento da pretensão, e é resultado da vontade unilateral do credor (art. 202, I a V, CC) ou do devedor (art. 202, VI, $\mathrm{CC})$.

A aparente contradição apontada pode ser solucionada adotando-se interpretação sistemática e teleológica do regime da prescrição. Posto que proscrita a possibilidade de as partes, de comum acordo, alterarem os prazos prescricionais, levando-se em consideração que a ampliação do prazo é consequência necessária da interrupção e que é resultado da vontade exclusiva de uma das partes, afigura-se possível admitir que as partes, após o início da contagem do prazo, acordem o seu alongamento. Câmara Leal (1982), embora sob a égide do Código Civil de 1916, que, como se observou, silenciava quanto à possibilidade da alteração convencional do prazo, admitia sua ampliação nas condições ora propostas, tendo em vista equipararem-se os efeitos dessa situação aos efeitos da interrupção:

Que é a interrupção da prescrição senão um alongamento de seu prazo? Se o prescribente pode interromper, por ato de sua vontade, reconhecendo o direito do titular, é claro que pode prolongar o prazo da prescrição, porque outro não é o efeito da interrupção (LEAL, 1982, p. 53).

\footnotetext{
48 Como sustenta Zimmermann (2002, p. 165), "the parties must be free to devise a most appropriate regime, as long as they observe the general limitations placed on freedom of contract".

49 Cahali (2012, p. 51) admite, no plano doutrinário, flexibilização do art. 192, a ratificar a possibilidade de se conferir maior espaço de atuação à autonomia privada, sem que isso importe em irremediável lesão à segurança jurídica e ao interesse público: "Na realidade, no plano doutrinário, seria sustentável certa flexibilidade do prazo de prescrição, segundo o que viesse a ser convencionado pelas partes, em especial quando se considera que o próprio Código Civil admite a decadência convencional, sem qualquer restrição (art. 211). Diríamos que algumas prescrições, para as quais a lei marcou prazo inferior a dez anos, poderiam, quando a ordem pública não fosse interessada, ser prolongada por convenção das partes até aquele limite previsto na disposição subsidiária do art. 205".
} 
Na mesma direção, e já sob a vigência do atual art. 192, Silvio de Salvo Venosa $(2016$, p. 605) admite a extensão do prazo, ao argumento de que

[...] a interrupção da prescrição nada mais é do que um prolongamento de seu curso. Se o titular pode interromper a prescrição, por ato de sua vontade, reconhecendo o direito de outrem, é evidente que pode prolongar o prazo da prescrição. O que o prescribente não pode fazer é estender o prazo prescricional com relação a prazo por decorrer, porque isso importaria em renúncia antecipada.

Em homenagem à coerência do sistema, o alongamento proposto deve ocorrer até o limite do dobro do prazo legal. Esse limite é inferido da própria disciplina da interrupção, que destrói a eficácia do tempo pretérito e reinicia a contagem do prazo prescricional em sua integralidade. Assim, a interrupção do prazo no seu último dia devolve o prazo total para o credor, a resultar, em termos práticos, na concessão de prazo equivalente ao dobro do estabelecido em lei. ${ }^{50}$ Ora, se esse efeito é admitido pela lei e merecedor de tutela quando resultado de atuação exclusiva de um dos contratantes, com maior razão, deve ser também admitido e igualmente merecedor de tutela quando produto do exercício da autonomia privada de ambas as partes. Em suma, poderão os contratantes, no exercício de sua autonomia, ajustar a extensão do prazo em curso até que o lapso já transcorrido, somado à dilação, alcance o dobro do prazo legal. No entanto, como a interrupção somente pode ocorrer uma vez, a dilação convencional do prazo impediria a posterior interrupção da prescrição, ${ }^{51}$ assim como, de maneira inversa, a interrupção da prescrição obstaria a posterior dilação convencional do prazo.

Seja como for, a despeito da alteração dos prazos prescricionais pelas partes não contrariar a ratio da prescrição, e de que a solução proposta - fixação de prazos mínimo e máximo dentro dos quais a autonomia privada estaria autorizada a atuar - pareça garantir o delicado equilíbrio entre os diversos interesses envolvidos, fato é que a vedação consta expressamente da lei, pelo que, por ora, a imperatividade dos prazos é a solução que se impõe $e^{52}$ - salvo na hipótese aventada de dilação até o limite do dobro do prazo, ajustada no curso da prescrição -, fulminando-se de nulidade qualquer convenção que pretenda alterá-los (THEODORO JÚNIOR, 2005, p. 202), conforme decidiu o Tribunal de Justiça do Paraná ao apreciar pedido de reembolso de despesas com medicamentos formulado por contratante de plano de saúde. A contratada alegava a prescrição da pretensão, nos termos de cláusula contratual, segundo a qual "o contratante perderá o direito ao reembolso decorridos doze meses da data do evento ou ao término do contrato se ocorrer antes". O Tribunal, fundandose no art. 192, alegou a nulidade da cláusula, que pretendia alterar o prazo prescricional de 10 anos (art. 205) aplicável à hipótese, na esteira da jurisprudência do Superior Tribunal de Justiça. ${ }^{53}$

A rigor, a vedação à alteração dos prazos prescricionais não é a única restrição à autonomia privada constante do art. 192; outras limitações surgem do dispositivo, restringindo ainda mais a liberdade das partes. É o que se passa a examinar.

50 Sob a vigência do Código Civil de 1916, Carpenter (1958, p. 162-163) admitia o prolongamento do prazo prescricional em curso pelo mesmo período da prescrição fiado em lei: "É válida a convenção que prolonga o prazo da prescrição em curso? Válida é tal convenção, uma vez que o prazo pelo qual é prolongada a prescrição não exceda o prazo da prescrição marcado na lei. 'Seria singular', diz Lyon-Caen, 'que assim não fosse, porque a lei admite a interrupção da prescrição, inclusive por ato de reconhecimento do devedor, posterior ao vencimento da dívida, e porque a interrupção inutilizando o tempo já decorrido conduz, em definitiva, a uma prolongação do prazo findo o qual o devedor pode invocar a prescrição'. Na verdade, quem pode o mais deve poder o menos. Se o prescribente pode interromper a prescrição, prolongando o seu prazo por tempo igual ao que ela tem por lei, porque não poderá convencionar com o titular ou sujeito da ação, com aquêle a quem a ação pertence, um prolongamento por tempo igual ou menor que êsse que a prescrição tem por lei?".

51 Ressalvada a interrupção em razão do despacho do juiz que ordenasse a citação (art. 202, I, CC), hipótese em que se tem sempre admitido, com razão, uma segunda interrupção (TEPEDINO et al., 2007, p. 383-384).

52 Entendimento diverso se aplica no plano do direito internacional, conforme destaca Jacob Dolinger (2001, p. 365). De acordo com o autor, embora no direito brasileiro as normas sobre prescrição não possam ser alteradas pelas partes, no plano internacional, a prescrição não encerra norma de ordem pública, pelo que não há "nenhum obstáculo à aplicação no Brasil de prazos prescricionais do direito estrangeiro, mais longos do que nossos prazos". Disponível em: <http://bibliotecadigital.fgv.br/ojs/index.php/rda/article/view/47251/44662>. Acesso em: 8 abr. 2017.

53 Lê-se do voto do Relator: "Assim, conclui-se ser nula a cláusula 11.4 do contrato entabulado entre as partes, visto que em desconformidade com o disposto no art. 192, do Código Civil” (TJPR, 9a CC, Rel. Des. Sérgio Luiz Patitucci, AC 1369606-3, julg. 9.6.2015). Note-se que, mesmo na ausência da proibição legal, a redução pretendida do prazo prescricional não seria admitida, por se tratar de cláusula limitativa do direito do consumidor. 


\subsection{Possíveis desdobramentos da imperatividade dos prazos prescricionais}

Afirma-se, em respeito à sistematicidade do regime da prescrição, que se a lei veda qualquer convenção que altere os prazos prescricionais, há que se entender vedadas todas as modificações do regime legal que, indiretamente, acabem por conduzir à alteração dos prazos, a exemplo do que ocorreria se fossem criadas, pelas partes, novas hipóteses de suspensão ou interrupção (LÔBO, 2015, p. 326) se fosse estabelecido termo a quo diverso do legal, ou se fosse ajustada a imprescritibilidade da pretensão (TEPEDINO et al., 2007, p. 616).

De acordo com Humberto Theodoro Júnior (2005, p. 202), se o art. 192 impede qualquer convenção que modifique os prazos prescricionais, "o impedimento há de prevalecer tanto para os negócios que diretamente ajustam prazos diferentes dos fixados em lei, como para as modificações indiretas obtidas por meio de convenções inovativas em torno das causas de suspensão ou interrupção". ${ }^{4}$

De outro lado, há autores, como Sílvio de Salvo Venosa (2016, p. 611), que admitem a ampliação, em casos excepcionais, das hipóteses de suspensão da prescrição: "quando há obstáculo invencível, independente da vontade do interessado, como, por exemplo, a desídia do escrivão do processo, é preciso entender ser caso de suspensão da prescrição". A rigor, a situação suscitada decorre da disciplina da prescrição intercorrente, que se verifica no curso de ação judicial apenas quando há inércia do autor em dar andamento ao processo, não já quando a morosidade processual se deve a fatores externos à sua vontade. Diversamente da prescrição ordinária, a intercorrente pode ser interrompida ilimitadamente, e recomeça a contar "do último ato do processo para a interromper", nos termos do parágrafo único do art. $202 .^{55}$

Caio Mário da Silva Pereira (2017, p. 584), por sua vez, admite a não taxatividade do rol relativo às causas de suspensão, e sustenta que também "não corre na pendência de um acontecimento que impossibilite alguém de agir, seja como consequência de uma determinação legal, seja por um motivo de força maior, seja por uma convenção". Na mesma direção, Gustavo Kloh Müler Neves (2008, p. 60) afirma que entender como taxativo o rol do art. 198 é "esvaziar uma proteção que é reputada importante não só pelo intérprete, mas também por quem elaborou os textos dos Códigos, porque o 'espírito' que se extrai do dispositivo é exatamente esse: a proteção dos que não podem evitar a própria inação". Nessa direção, defende o autor que "se a alguém, em um dado momento, não for possível resistir a uma lesão, não se poderá iniciar a contagem do prazo prescricional, e se este houver sido iniciado deverá ser tido por suspenso, posto que não haja causa de suspensão arrolada na lei” (NEVES, 2008, p. 90), como ocorre, por exemplo, quando há interposição de recurso administrativo. ${ }^{56}$

Sustenta-se, ainda, decorrer do art. 192, a inalterabilidade do termo a quo da prescrição. Essa foi, precisamente, uma das razões pelas qual o Superior Tribunal de Justiça, ao examinar o termo a quo da prescrição da ação de execução de cheque cuja "data de emissão" inserida na cártula era 31.7.2006 - embora as partes tenham combinado a apresentação para o dia 1/12/2006 -, firmou entendimento segundo o qual o ajuste extracartular não é capaz de alterar o termo inicial da prescrição da ação de execução. De acordo com a Relatora Ministra Nancy Andrighi,

ainda que a emissão de cheques pós-datados seja prática costumeira, não encontra previsão legal. Admitir-se que do acordo extracartular decorra a dilação do prazo prescricional, importaria na alteração da natureza do cheque como ordem de pagamento à vista e na infringência do art. 192 do CC, além de violação dos princípios da literalidade e abstração. [...] O termo inicial de contagem

\footnotetext{
4 E prossegue o autor na mesma sede: "Se se reconhece que tais prazos se acham sob regime normativo de ordem pública, não cabe ao negócio jurídico pré-excluir causa legal de suspensão ou interrupção, nem tampouco criar novas causas obstativas nesse terreno, já que, em última análise, representariam ampliações do lapso fixado na lei”. No mesmo sentido, confira-se Gonçalves (2016, p. 533).

Sobre prescrição intercorrente, confira-se Pereira (2017, p. 574).

56 Sob a égide do Código Civil de 1916, Carvalho Santos (1984, p. 405; confira-se, também, p. 411-412). noticiava: "Mas a doutrina admite que a prescrição não corra contra aquele que se acha na impossibilidade absoluta de agir, em virtude de uma causa objetiva, como, por exemplo, a força-maior que impeça a pessoa de agir [...]. Neste ponto a doutrina não é pacífica [...]. A jurisprudência dos nossos tribunais, como vamos ver dentro em pouco, está de acordo com a doutrina mais aceita".
} 
do prazo prescricional da ação de execução do cheque pelo beneficiário é de 6 (seis) meses, prevalecendo, para fins de contagem do prazo prescricional de cheque pós-datado, a data nele regularmente consignada, ou seja, aquela oposta no espaço reservado para a data de emissão. ${ }^{57}$

Sob o mesmo fundamento, o Superior Tribunal de Justiça, instado a analisar contrato de mútuo habitacional cujo inadimplemento ensejou o vencimento antecipado das prestações, consoante estabelecido no contrato, decidiu que

[...] o vencimento antecipado da dívida livremente pactuado entre as partes, por não ser uma imposição, mas apenas uma garantia renunciável, não modifica o início da fluência do prazo prescricional, prevalecendo, para tal fim, o termo ordinariamente indicado no contrato, que, no caso do mútuo imobiliário, é o dia do vencimento da última parcela (arts. 192 e 199, II, do CC). ${ }^{58}$

Da regra do art. 192 extrai-se, por fim, a impossibilidade de declaração de imprescritibilidade pelas partes contratantes. A imprescritibilidade decorreria, segundo se afirma, da lei ou da natureza do direito, jamais da vontade das partes. ${ }^{59} \mathrm{~A}$ Constituição da República determina, por exemplo, no art. $5^{\circ}$, inciso XLII, a imprescritibilidade da pretensão punitiva do crime de racismo. O Constituinte atribuiu tutela privilegiada a interesse que considerou mais relevante do que a segurança jurídica: a repressão ao racismo. De outro lado, no que tange à imprescritibilidade decorrente da natureza do direito, Clóvis Beviláqua (1959, p. 355) já afirmava que "os direitos patrimoniais é que são prescritíveis. Não há prescrição senão de direitos patrimoniais. Os direitos que são emanações diretas da personalidade e os da família, puros, não prescrevem".

Nessa esteira, a jurisprudência há muito reconhece a imprescritibilidade de algumas ações de estado, a exemplo da ação de investigação de paternidade, considerada imprescritível pela Súmula 149 do Supremo Tribunal Federal desde 1963.

Compreender a segurança jurídica não como o único, mas apenas como um dos interesses constitucionalmente tutelados conduz, contudo, a maior flexibilização do instituto da prescrição. Sob tal perspectiva, a imprescritibilidade resultaria, sobretudo, da prevalência de ouros princípios constitucionais, a exemplo da proteção e promoção da dignidade da pessoa humana, quando ponderados com o princípio da segurança jurídica. Como destaca Anderson Schreiber (2013, p. 91), "[...] a imprescritibilidade não é um dogma atrelado a certas situações jurídicas, mas o efeito da prevalência específica de outro interesse público que, naquelas circunstâncias, é tutelado pela Constituição da República de modo ainda mais intenso que a segurança jurídica".

Com efeito, por vezes, é o próprio constituinte que realiza tal ponderação, estabelecendo a imprescritibilidade de certa pretensão, a exemplo do já mencionado art. $5^{\circ}$, inciso XLII. Em outras, no entanto, a ponderação é levada a cabo pelo intérprete, como ocorreu em relação à pretensão indenizatória decorrente de violação de direitos fundamentais durante o período de exceção, cuja imprescritibilidade foi reconhecida pelo Superior Tribunal de Justiça. ${ }^{60} \mathrm{Em}$ se tratando, por conseguinte, de tortura praticada durante o regime militar de exceção, o Egrégio Tribunal conferiu primazia à tutela da dignidade da pessoa

BRASIL. STJ, 2 ${ }^{\text {a }}$ S., Rel. Min. Nancy Andrighi, REsp 1068513/DF, julg. 14.9.2011.

BRASIL. STJ, $3^{a}$ T., Rel. Min. Ricardo Villas Bôas Cueva, REsp 1.489.784/DF, julg. 15.12.2015. Em seu voto, desenvolve o Ministro Relator: "Desse modo, como o vencimento antecipado da dívida livremente pactuado entre as partes não pode ser considerado uma imposição na ocorrência da inadimplência do mutuário, sendo somente uma garantia do credor, que pode ser renunciada, o termo ordinariamente indicado na avença não é alterado, inclusive para fins prescricionais (art. 192 do CC). De fato, não corre a prescrição não estando vencido o prazo fixado contratualmente (art. 199, II, do CC). Em outras palavras, o vencimento antecipado da dívida não altera o início da fluência do prazo prescricional, prevalecendo, para tal fim, o termo ordinariamente indicado no contrato, que, no caso (mútuo imobiliário), é o dia do vencimento da última parcela".

59 Sobre imprescritibilidade, confira-se Leal (1982, p. 36 et. seq.).

60 BRASIL. STJ, $1^{\text {a }}$ T., Rel. Min. José Delgado, REsp 379.414/PR, julg. 26.11.2002. 
humana em detrimento da segurança jurídica, reconhecendo nova hipótese de pretensão imprescritível não prevista expressamente em lei. ${ }^{61}$

\section{Conclusão}

O reconhecimento de que a prescrição se fundamenta na promoção da segurança jurídica e encerra instituto de ordem pública inspirou o legislador a elaborar regime jurídico em que pouco espaço é conferido à autonomia privada. A renúncia e a possibilidade de interrupção dos prazos prescricionais, posto que regulados minuciosamente por normas cogentes, conferem alguma liberdade às partes, revelando-se como um dos poucos aspectos da prescrição em relação ao qual a autonomia privada é convidada a atuar.

Observa-se, assim, que o exercício da autonomia privada não está proscrito da disciplina da prescrição, e que é possível nela reconhecer aspectos privatistas sem afastar sua conotação de ordem pública. Com efeito, a regulamentação pelas partes de interesses privados patrimoniais pode conviver em harmonia com as normas cogentes da prescrição, sem importar em ameaça à segurança jurídica, desde que observados os contemporâneos parâmetros do exercício legítimo da autonomia privada, e que a disciplina estabelecida pelos contratantes não afaste ou embarace a incidência do instituto da prescrição do caso concreto.

Embora o legislador de 1916 tenha silenciado quanto ao tema, o legislador de 2002, no art. 192, afastou qualquer possibilidade de modificação dos prazos pelas partes, o que acaba por lhes impor outras restrições, como a vedação à criação de novas hipóteses de suspensão ou interrupção - segundo se afirma -, ao ajuste de termo a quo diverso do legal e ao estabelecimento da imprescritibilidade da pretensão.

O legislador de 2002 foi de encontro à tendência observada em países como Alemanha e França, nos quais recentes reformas legislativas ampliaram a atuação da autonomia privada, e admitiram a alteração dos prazos. Ao que parece, o art. 192 restringiu desproporcionalmente a liberdade das partes, já que seria possível tutelar a segurança jurídica e, ao mesmo tempo, prestigiar a autonomia privada, definindose prazos legais mínimos e máximos dentro dos quais os contratantes poderiam escolher aquele que melhor promovesse seus interesses privados patrimoniais. Nesse cenário, homenagear-se-ia a autonomia privada, sem descurar dos interesses resguardados pela prescrição.

De todo modo, embora, de lege lata, a possibilidade de modificação dos prazos prescricionais pelas partes esteja vedada, cabe ao intérprete buscar soluções, dentro da legalidade constitucional, que prestigiem a autonomia privada legitimamente exercida. Nesse sentido, afigura-se possível permitir aos contratantes a dilação do prazo prescricional, após o termo a quo, até o dobro do prazo legal. Ora, se uma das partes pode, unilateralmente, interromper o curso da prescrição e reiniciá-la - o que pode, na prática, dobrar o prazo prescricional -, com muito mais razão deve-se admitir que os contratantes, de comum acordo, alcancem o mesmo resultado.

\section{Referências}

AMARAL, Francisco. Direito civil - Introdução. 6. ed. Rio de Janeiro: Renovar, 2006.

AMAYUELAS, Esther Arroyo. Efectos de la prescripción extinctiva. In: JORNADAS DE LA ASOCIACIÓN DE PROFESORES DE DERECHO CIVIL LA PRESCRIPCIÓN EXTINTIVA. XVII. Valencia: Tirant lo Blanch, 2014. p 235-318

61 Confira-se, mais recentemente, a seguinte decisão da $2^{a}$ Turma: "[...] A jurisprudência do STJ é pacificada no sentido de que a prescrição quinquenal, disposta no art. $1^{\circ}$ do Decreto 20.910/1932, é inaplicável aos danos decorrentes de violação de direitos fundamentais, que são imprescritíveis, principalmente quando ocorreram durante o Regime Militar, época na qual os jurisdicionados não podiam deduzir a contento suas pretensões. Ressalte-se que a afronta aos direitos básicos da pessoa humana, como a proteção da sua dignidade lesada pela tortura e prisão por delito de opinião durante o Regime Militar de exceção, enseja ação de reparação ex delicto imprescritível e ostenta amparo constitucional no art. $8^{\circ}, \S 3^{\circ}$, do Ato das Disposições Constitucionais Transitórias [...]" BRASIL. STJ, $2^{a}$ T., Rel. Min. Herman Benjamin, Resp1577411/SP, julg. 23.2.2016. 
BEHAR-TOUCHAIS. Martine. Foisonnment des délais. In: COURBE, Patrick (Org.). Les désordres de la prescription. Rouen: Université de Rouen, 2000. p .12-18.

BEVILAQUA, Achiles. Código Civil brasileiro. 11. ed. Rio de Janeiro: Paulo de Azevedo, 1954.

BEVILAQUA, Clovis. Teoria geral do direito civil. 7. ed. São Paulo: Paulo de Azevedo, 1955.

BEVILAQUA, Clovis. Código Civil dos Estados Unidos do Brasil comentado. 12. ed. Rio de Janeiro: Livraria Francisco Alves, 1959. v. 1.

BIANCA, Massimo C. Técnicas de formación del contrato y tutela del contratante débil: el principio de buena fe en el Derecho Privado Europeu. In: CÓRDOBA, Marcos M. (Dir.). Tratado de la buena fe en el derecho. Buenos Aires: La Ley, 2004. t. 2. p.189-204.

BIGOT-PRÉAMENAU. A prescrição na exposição de motivos do Code Civil. Recueil complet des travaux préparatoires du code civil. t. XV, p. 575. Disponível em: <http://gallica.bnf.fr/ark:/12148/ bpt6k1134765/f578>. Acesso em: 20 abr. 2017.

BODIN DE MORAES, Maria Celina A causa dos contratos. Revista Trimestral de Direito Civil, Rio de Janeiro, n. 21, p. 95-119, jan./mar. 2005.

CAHALI, Yussef Said. Prescrição e decadência. 2. ed. rev. e atual. São Paulo: Revista dos Tribunais, 2012.

CANARIS, Claus-Wilhelm. O novo direito das obrigações na Alemanha. Revista da EMERJ, v. 7, n. 27, , p. 108-136, 2004.

CARIO, Robert. Les modifications conventionnelles de la prescription extinctive. Paris: Petites Affiches, 1998.

CARPENTER, Luiz F. Da prescrição (arts. 161 a 179 do Código Civil). 3. ed. atualização e notas de Arnold Wald. Rio de Janeiro: Nacional de Direito, 1958.

CARVALHO SANTOS, J. M. Código Civil interpretado. 10. ed. Rio de Janeiro: Freitas Bastos, [s.d], v. 3.

DANTAS, San Tiago. Programa de Direito Civil - Teoria Geral, ed. rev. e at. por TEPEDINO, Gustavo et. al., Rio de Janeiro: Forense, 2001.

DINIZ, Maria Helena. Curso de direito civil brasileiro - Teoria geral do direito civil. 26. ed. São Paulo: Saraiva, 2009.

DOLINGER, Jacob. Ordem pública - Prescrição - Direito Comparado. Revista de Direito Administrativo. Rio de Janeiro, Editora FGV, v. 226, p. 352-365, 2001, Disponível em: < http:// bibliotecadigital.fgv.br/ojs/index.php/rda/article/view/47251/44662>. Acesso em: 08 abr. 2017.

FAUVARQUE-CAUSSON, Bénédicte ; MAZEAUD, Denis. L'avant-projet français de réforme du droit des obligations et du droit de la prescription. Revue de Droit Uniforme. Oxford: Oxford Univeristy Press, v. 11, p. 103-134, 2006.

FERRI, Luigi. La autonomia privada. Tradução de Luis Sancho Mendizábal. Granada: Comares, 2001.

FLOUR, Jacques; AUBERT, Jean-Luc; SAVAUX, Éric. Droit civil. Les obligations. 3. Le rappor d'obligation. 9. ed. ebook, Paris: Sirey, 2015.

FRANCO, Ary Azevedo. A prescrição extintiva no Código Civil brasileiro (Doutrina e jurisprudência). Rio de Janeiro: Freitas Bastos, 1940.

GOMES, Orlando. Introdução ao direito civil. 17. ed. Rio de Janeiro: Forense, 2000.

GONÇALVES, Carlos Roberto. Direito civil brasileiro. 14. ed. São Paulo: Saraiva, 2016. v. 1.

GUIMARÃES, Carlos da Rocha. Prescrição e decadência. Rio de Janeiro: Forense, 1980.

KONDER, Carlos Nelson de Paula. Distinções hermenêuticas da constitucionalização do direito civil: o intérprete na doutrina de Pietro Perlingieri. Revista da Faculdade de Direito - UFPR, Curitiba, v. 60, n. 1, p. 193-213, jan./abr. 2015. 
LANDO, Ole. Is good faith an overarching general clause in the principles of European contract law? In: ANDENAS, Mads et al. Liber amicorum Guido Alpa: private law beyond the national systems. London: British Institute of International and Comparative Law, 2007. p. 601-613.

LEAL, Antônio Luis da Câmara. Da Prescrição e Decadência. 4. ed. atualizado por DIAS, José de Aguiar, Rio de Janeiro: Forense, 1982.

LÔBO, Paulo. Direito civil: parte geral. 5. ed. São Paulo: Saraiva, 2015.

LOUBSER, Max. Towards a theory of extinctive prescription. South African Law Journal, Centurion: Sabinet, v. 105, p. 34-53, 1988.

MAINE, Henry Sumner. Ancient Law. Londres: Hazel, Watson and Viney Ed, 1906.

MARTINS-COSTA, Judith. Notas sobre o princípio da função social do contrato. Revista Literária de Direito, São Paulo, n. 37, p. 17-21, ago./set. 2004.

MENCK, José Theodoro Mascarenhas. Código Civil brasileiro no debate parlamentar: elementos históricos da elaboração da lei n. 10.406, de 2002. Brasília: Edições Câmara, 2012. t. I a IV.

MENDONÇA, Manoel Ignacio Carvalho de. Doutrina e prática das obrigações. Curitiba: Imprensa Paranaense, 1908.

MENEZES CORDEIRO, António. A posse: perspectivas dogmáticas actuais. 3. ed. Coimbra: Almedina, 2005.

MENEZES CORDEIRO, António. Da boa fé no direito civil. Coimbra: Almedina, 2001.

MENEZES CORDEIRO, António. A modernização do Direito das Obrigações. Revista da Ordem dos Advogados. Ano 62. vol. 1, Lisboa, jan. 2002. Disponível em: <https://portal.oa.pt/comunicacao/ publicacoes/revista/ano-2002/ano-62-vol-i-jan-2002/artigos-doutrinais/antonio-menezes-cordeiro-amodernizacao-do-direito-das-obrigacoes/>. Acesso em: 4 abr. 2017.

MOSCATI, Enrico. Autonomia privata e giustizia contrattuale (note minime sul controllo del contenuto del contratto e della congruità dei termini dello scambio). In: TORRE, Giuseppe Dalla. Studi in onore di Giovanni Giacobbe. Milano: Giuffrè, 2010. t. 2. p. 1201-1220.

NEGREIROS, Teresa. Teoria do contrato: novos paradigmas. Rio de Janeiro: Renovar, 2002.

NEVES, Gustavo Kloh Müller. Prescrição e decadência no direito civil. 2. ed. Rio de Janeiro: Lumen Juris, 2008.

NICOLAU JR., Mauro; ALMEIDA, Ricardo Marques de. Prescrição, cláusulas gerais e segurança jurídica - Perspectivas hermenêuticas dos direitos fundamentais no Código Civil. In: CIANCI, Mirna (Coord.).

Prescrição no Código Civil: uma análise interdisciplinar. 2. ed. São Paulo: Saraiva, 2006. p. 413-512.

NORDMEIER, Carl Friedrich. O novo direito das obrigações no Código Civil alemão - A reforma de 2002.

Revista Cadernos do Programa de Pós-Graduação em Direito PPGDir/UFRGS, Porto Alegre, n. 1, p. 218-219, 2004. Disponível em: <http://seer.ufrgs.br/index.php/ppgdir/article/view/43502/27380>. Acesso em: 4 abr. 2017.

PEREIRA, Caio Mário da Silva. Instituições de direito civil. Atualizado por Maria Celina Bodin de Moraes. 30. ed. Rio de Janeiro: Forense, 2017. v. 1.

PEREIRA, Caio Mário da Silva. Instituições de direito civil. 16. ed. Rio de Janeiro: Forense, 1994. v. 1. PERLINGIERI, Pietro. Manuale di diritto civil. Napoli: Scientifiche Italiane, 2005.

PERLINGIERI, Pietro. Relazione di sintesi. In: FERRONI, Lanfranco (Coord.). Equilibrio delle posizioni contrattuali ed autonomia privata. Napoli: Scientifiche Italiane, 2002. p. 165-176.

PERLINGIERI, Pietro. Nuovi profili del contratto. Rassegna di Diritto Civille, Napoli, v.21, n.3, p. 543$571,2000$.

PERLINGIERI, Pietro. Complessità e unitarietà dell'ordinamento giuridico vigente. Rassegna di Diritto Civile. Napoli: Edizioni Scientifiche Italiane, v.1/5. p. 188-216, 2005. 
PONTES DE MIRANDA, Francisco Cavalcanti. Tratado de direito privado. Atualização de Otavio Luiz Rodrigues Junior, Tilman Quarc e Jefferson Carús Guedes. São Paulo: Revista dos Tribunais, 2013. v. 6.

REALE, Miguel. Lições preliminares de direito. 24. ed. São Paulo: Saraiva, 1999.

RIZZARDO, Arnaldo. Parte geral do Código Civil: Lei no 10.406, de 10.01.2002. 5. ed. rev. e atual. Rio de Janeiro: Forense, 2007.

ROSELLI, Federico. La prescrizione e la decadenza. In: LIPARI, Nicolò; RESCIGNO, Pietro (Dir.); ZOPPINI, Andrea (Coord.). Attuazione e tutela dei diritti: l'attuazione dei diritti., Milano: Giuffrè, 2009. v.4. t. 2. p. 487-532.

SAVIGNY, Carl von. System des heutigen römischen Rechts. Berlim: Seit Deit Comp, 1841. v. 5. p. 272. Disponível em: <http://dlib-pr.mpier.mpg.de/m/kleioc>. Acesso em: 10 abr. 2017.

SCHREIBER, Anderson. Abuso do direito e boa-fé objetiva. In: SCHREIBER, Anderson. Direito civil e constituição. São Paulo: Atlas, 2013, p. 49-60.

SCHREIBER, Anderson. A decadência da prescrição? Direito civil e constituição. São Paulo: Atlas, 2013.

SCHREIBER, Anderson. Direito civil e constituição. In: SCHREIBER, Anderson; KONDER, Carlos Nelson de Paula (Org.). Direito civil constitucional. São Paulo: Atlas, 2016, p. 1-23.

LOPES, Miguel Maria de Serpa. Curso de direito civil. 7. ed. Rio de Janeiro: Freitas Bastos, 1989. v. 1.

SPADAFORA, Antonio. La regola contrattuale tra autonomia privata e canone di buona fede: prospettive di diritto europeo dei contratti e di diritto interno. Torino: G. Giappichelli Editore, 2007.

TEPEDINO, Gustavo. Diálogos entre fontes normativas na complexidade do ordenamento. Revista Brasileira de Direito Civil - RBDCivil, Rio de Janeiro, v. 5, p. 6-9, jul./set. 2015. Disponível em: <https:// www.ibdcivil.org.br/rbdc.php?ip=123\&titulo=\%20VOLUME\%205\%20|\%20Jul-Set\%202015\&category_ id=97\&arquivo=data/revista/volume5/rbdcivil-vol5-12.01.16.pdf>. Acesso em: 30 dez. 2015.

TEPEDINO, Gustavo. Notas sobre a função social do contrato. In: TEPEDINO, Gustavo. Temas de direito civil. Rio de Janeiro: Renovar, 2009. t. 3. p. 395-405.

TEPEDINO, Gustavo; SCHREIBER, Anderson. A boa-fé objetiva no Código de Defesa do Consumidor e no novo Código Civil. In: TEPEDINO, Gustavo (Coord.). Obrigações: estudos na perspectiva civilconstitucional. Rio de Janeiro: Renovar, 2005. p. 29-44.

TEPEDINO, Gustavo. Notas sobre a cláusula penal compensatória. In: TEPEDINO, Gustavo. Temas de direito civil. Rio de Janeiro: Renovar, 2006. t. 2. p. 47-61.

TEPEDINO, Gustavo. As relações de consumo e a nova teoria contratual. In: TEPEDINO, Gustavo. Temas de direito civil. 4. ed. Rio de Janeiro: Renovar, 2008, t. 1. p. 229-250.

TEPEDINO, Gustavo; BARBOZA, Heloisa Helena; BODIN DE MORAES, Maria Celina. Código Civil interpretado conforme a Constituição da República. vol. 1, 2. ed. rev. e atual., Rio de Janeiro: Renovar, 2007.

TEPEDINO, Gustavo. Premissas metodológicas para a constitucionalização do direito civil. In: TEPEDINO, Gustavo. Temas de direito civil. 4. ed. rev. e atual. Rio de Janeiro: Renovar, 2008. t. 1. p. $1-23$.

TERRA, Aline de Miranda Valverde. Liberdade do intérprete na metodologia civil constitucional. In: SCHREIBER, Anderson; KONDER, Carlos Nelson de Paula (Org.). Direito civil constitucional. São Paulo: Atlas, 2016. p. 47-70.

THEODORO JÚNIOR, Humberto. Comentários ao novo Código Civil. 3. ed. Rio de Janeiro: Forense, 2005. v. 3. t. II.

TOMLINS, T. E. The law dictionary. Londres: C. and. R. Baldwin, 1810. v. 2. 
TRIGGIANO. Annalisa. Short Remarks on Extinctive Prescription in Legal History. US-China Law Review, n. 10, p. 40-41, 2017. Disponível em: < http://www.davidpublishing.com/davidpublishing/ Upfile/3/4/2013/2013030410932830.pdf>. Acesso em: 17 abr. 2017.

VENOSA, Sílvio de Salvo. Direito civil. 16. ed. São Paulo: Atlas, 2016. v. 1.

VINEY, Geneviève. Synthèse des travaux. In: JOURDAN, Patrice; WÉRY, Patrick. La prescription extinctive - Études de Droit Comparé. Bruxelas: Bruylant, 2011.p. 984-1010

VIVEIROS DE CASTRO, Thamis Dalsenter. Bons costumes no direito civil brasileiro. São Paulo: Almedina, 2017.

WINDSCHEID, Bernhard. II diritto delle pandette. Torino: Unione Tipografico-Editrice Torinese, 1930. v. 1.

ZIMMERMANN, Reinhard. Comparative foundations of a European law of set-off and prescription. Cambridge: Cambridge University Press, 2002.

ZIMMERMANN, Reinhard. EI nuevo derecho alemán de obligaciones: un análisis desde la historia y el derecho comparado. Tradução de Esther Arroyo i Amayuelas. Barcelona: Bosch, 2008.

Recebido em: 06/08/2017

Aprovado em: 27/11/2017 